\title{
Urological Pathologies and Their Incidence Rates Determined in Cases Applied to the Health Board
}

\author{
Sağlik Kuruluna Başvuran Olgularda Tespit Edilen Ürolojik \\ Patolojiler ve S1klikları
}

\section{Deniz Noyan Ozlu (1), Ekrem Guner (D)}

Department of Urology, University of Health Sciences, Dr. Sadi Konuk Training and Research Hospital, Istanbul, Turkey

Cite as: Ozlu DN, Guner E. Urological pathologies and their incidence rates determined in cases applied to the health board. Grand J Urol 2021;1(3):89-95.

\author{
Submission date: 30 May 202 \\ Acceptance date: 02 July 2021 \\ Online first: 05 August 2021 \\ Publication date: 20 September 2021 \\ Corresponding Author: Deniz Noyan Ozlu / University of Health Sciences, Dr. Sadi Konuk Training and Research Hospital, Istanbul, Turkey / \\ noyanozlu@hotmail.com ORCID ID: 0000-0003-2435-5482
}

\begin{abstract}
Objective: Applications are made to health boards for age assessment, gender determination, employment in some occupational groups and detection of disability. The aim of our study is to determine the defined urological pathologies and their incidence rates in the patients who applied to the health board of our hospital. Materials and Methods: Our study included patients who applied to the urology outpatient clinic of the health board between January 2015 and December 2020 for the purpose of employment in some occupational groups, determination of age, gender, disabilities and obtaining a general health report. Patients were investigated in two different groups, according to their indications for their applications as detection of disabilities and other indications, and the diagnoses were classified under the subheadings of stone diseases, malignancies, neurourology-incontinence, andrology and benign prostatic hyperplasia (BPH).

Results: A total of 1453 cases were included in the study. Hundred and fifty-one (10.4\%) patients applied for the detection of disability. A total of 206 (17\%) patients, including $70(46.3 \%)$ cases in the disability detection group and $136(10.4 \%)$ in the other group had a urological diagnosis. The most common pathology was malignancies with $65(4.4 \%)$ cases, in order of frequency; testicular cancer $(n=25: 38.4 \%)$, bladder cancer $(n=15: 23 \%)$, prostate cancer $(n=13: 20 \%)$, kidney cancer $(\mathrm{n}=11: 16.9 \%)$ and penile cancer $(\mathrm{n}=1: 1,5 \%)$. The second most frequently seen diagnostic group was the stone disease group $(\mathrm{n}=55: 3.7 \%)$, and $17(30.9 \%)$ of them required further investigation after diagnosis. Consequently ESWL ( $\mathrm{n}=6: 10.9 \%)$, and surgical intervention $(\mathrm{n}=4: 7.3 \%)$ were planned for the indicated number of patients.

Conclusion: Urogenital system malignancies and urinary tract stones have been identified as the most common pathologies in patients who applied to the health board. The fact that some diseases, especially urolithiasis were followed by further examination and treatment, shows the contribution of the health board examinations to the treatment as well as the health status determination feature.
\end{abstract}

Keywords: health board, disability evaluation, urologic diseases, medical examination, health check

Öz

Amaç: Yaş ve cinsiyet tespiti, özür tespiti ve bazı meslek gruplarında işe alınma gibi durumlarda sağlık kurullarına başvurular yapılmaktadır. Çalışmamızın amacı hastanemizin sağlık kuruluna başvuran olgularda tanımlanmış ürolojik patolojileri ve sıklıklarını belirlemektir.

Gereçler ve Yöntemler: Çalışmamız Ocak 2015- Aralık 2020 tarihleri arasında, bazı meslek gruplarının işe alınma, yaş ve cinsiyet tayini, özür tespiti ve genel sağlık raporu alınması amacıyla sağlık kurulu üroloji polikliniğine başvuran hastaları içermektedir. Hastalar başvuru nedenlerine göre; özür tespiti için başvuranlar ve diğer nedenlerle başvuranlar olmak üzere iki ayrı grupta incelenmiş ve tanılar; taş hastalıkları, maligniteler, nöroüroloji-inkontinans, androloji ve bening prostat hiperplazisi (BPH) alt başlıklarında sınıflandırılmıştır.

Bulgular: Toplam 1453 olgu çalışmaya dahil edildi. Özür tespiti için başvuran olgu sayısı $151(\% 10,4)$ idi. Özür tespiti grubunda 70 (\%46,3), diğer grupta 136 $(\% 10,4)$ olmak üzere toplam $206(\% 17)$ hastada ürolojik bir tanı mevcuttu. En sik tespit edilen patoloji $65(\% 4,4)$ olgu ile malignitelerdi, sıklık sırasıyla; testis kanseri $(\mathrm{n}=25: \% 38,4)$, mesane kanseri $(\mathrm{n}=15: \% 23)$, prostat kanseri $(\mathrm{n}=13: \% 20)$, böbrek kanseri $(\mathrm{n}=11: \% 16,9$ ve penil kanser $(\mathrm{n}=1: \% 1,5)$. İkinci en sık görülen tanı grubu $55(\% 3,7)$ hasta ile taş hastalıklarıydı, $17(\% 30,9)$ 'sinde tanı konulması sonrası ileri inceleme gerekti, bunun sonucu olarak $6(\% 10,9)$ hastaya ESWL, $4(\% 7,3)$ hastaya cerrahi planlandi.

Sonuç: Ürogenital sistem maligniteleri ve üriner sistem taşları sağlık kuruluna başvuran hastalarda en sık rastlanan patolojiler olarak tespit edilmiştir. Ürolitiazis başta olmak üzere bazı hastalıkların ileri tetkik ve tedavi edilmiş olması, sağlık kurulunun sağlık durumu tespiti özelliğinin yanında tedaviye katkısını da göstermektedir.

Anahtar kelimeler: sağlık kurulu, özür tespiti, ürolojik hastalıklar, tıbbi muayene, sağlık kontrolü 


\section{Introduction}

In Turkey, a health board report is issued every day for many patients due to various health problems. In addition to requesting a general health report in cases such as determination of age, and gender, and for employment in some occupational groups, applications to health boards for the determination of disability constitute also an important place among these applications.

The term "disabled" in the legislation; is defined as "the person who has difficulties adapting to social life and meeting his/her daily requirements due to the loss of his/her physical, mental, spiritual, sensory and social abilities to various degrees due to any reason, and needs protection, care, rehabilitation, counseling and support services" [1]. Disability Health Board consists of specialists in internal medicine, ophthalmology, earnose-throat diseases, general surgery or orthopedics, neurology or mental health and diseases [2]. The fact that urology is outside of these standard branches is due to the relatively lesser number of applications made regarding urogenital system-related pathologies. However, the branch of urology is included in the evaluation process in the health board in cases of employment for a number of professional groups, age and gender determination and declaration or determination of a urological pathology.

Many studies have been performed in different specialties related to pathologies detected in patients who applied to the health board for detection of disability and for other indications $[1,3,4]$. However, there is no published article investigating the applications to the health board in the field of urology. The aim of our study is to determine the defined urological pathologies and their incidence rates in patients who applied to our hospital's medical board.

\section{Materials and Methods}

Our study included patients who applied to the urology outpatient clinic of Dr. Sadi Konuk Training and Research Hospital for a health board report between January 2015 and December 2020 for the purpose of employment in some occupational groups (police, security guards, military, etc.), and also for determining the age, gender, and disability status. The ethical approval of the study was obtained from the ethics committee of the same hospital (Dr. Sadi Konuk Training and Research Hospital Ethical Committee approval number: 2021/187). Patients of all age groups were included in the study and their medical files were retrospectively examined. Patients were examined in two different groups, according to the indications for their applications as detection of a disability and for other indications (employment, obtaining a general health report, and determination of age or gender, etc.).

The gender and age of the patients were examined, and their urological diagnoses were scanned mainly through the International Classification of Diseases-10 (ICD-10) codes. Also medical histories, physical examination, and if available, radiological and ultrasonographic findings of the applicants registered in the system were investigated. The diagnoses found were classified under the subheadings of urinary tract stone diseases, malignancies, neurourology-incontinence, andrology and benign prostatic hyperplasia (BPH).
Patients in the group of stone diseases were examined for the need for further examination and intervention. Malignancies were classified as prostate, bladder, renal, testicular and penile cancers. Less frequently encountered pathologies were presented under the heading of "others"; such as renal cysts, testicular and renal agenesis and hypoplasia, ureteropelvic junction (UPJ) obstruction, vesicoureteral reflux (VUR), and urethral stenosis. Urogenital system infections were not included in the study by us because they were not considered as adverse conditions and were recorded at a low rate.

\section{Statistical analysis}

Statistical analyses were performed using Microsoft Excel 2013 (Microsoft, Redmond, WA, USA). Continuous data were described as mean and range. Categorical data was described as percentages.

\section{Results}

A total of 1484 cases with a health board urology examination record were detected. A total of 1453 cases were included in the study considering the first application records of those who applied more than once. The mean age of the patients was 29.5 \pm 7.7 years, male patients constituted the majority $(\mathrm{n}=1381$ : $95 \%$ ), and only $72(5 \%)$ female patients included in the study. A total of $151(10.4 \%)$ cases with a mean age of $54.8 \pm 9.3$ years including $129(85.5 \%)$ male, and $22(14.5 \%)$ female patients applied for the detection of disability. Patients presenting for the determination of disability were older than the general population, as expected. The remaining patients were classified under the heading of "other".

A total of $206(14,3 \%)$ patients had received a urological diagnosis, including $70(4,9 \%)$ patients in the disability detection and $136(9,4 \%)$ cases in the other group. A urological pathology was identified in almost half of the patients in the disability detection group. The urological pathologies detected as a result of the study and their distribution among the groups are shown in Table 1.

The most common pathology was urogenital system malignancies with 65 (4.5\%) cases. At least one malignancy had been diagnosed in one-fourth (37/151) of the disabled group. In the other group of admissions, the frequency of malignancy fell to the second rank with 1,9 percent. Table 2 shows the distribution of detected uro-oncological diagnoses. The most common diagnosis in this group was testicular cancer $(\mathrm{n}=25: 38.4 \%)$ including 8 (32\%) cases in the disability detection group and $17(68 \%)$ in the other group. The mean age of these patients was $32.3 \pm 9.7$ years, and the most common pathological subgroup was pure seminoma with a rate of 40 percent. Bladder cancer was the second most common pathology, with a total of $15(23 \%)$ cases including 11 (73.3\%) patients in the disability detection group and 4 (26.7\%) patients in the other group. The mean age of these patients was $56.2 \pm 11$ years, and $6(40 \%)$ cases were cystectomized. Prostate cancer was the third most frequently encountered diagnosis with $13(20 \%)$ cases. The mean age of the patients was $57.9 \pm 7.5$ years. There were $10(76.9 \%)$ patients in the disability detection group and $3(23.1 \%)$ patients in the other group. Five (38.5\%) 
Table 1. Urological pathologies and their distribution between groups

\begin{tabular}{l|l|l|l}
\hline & $\begin{array}{l}\text { Applications for the detection of } \\
\text { disability } \mathbf{n = 1 5 1} \mathbf{( 1 0 , 4} \mathbf{\%})\end{array}$ & $\begin{array}{l}\text { Applications for other } \\
\text { indications } \mathbf{n = 1 3 0 2} \mathbf{( 8 9 . 6 \% )}\end{array}$ & $\begin{array}{l}\text { All applications n=1453 } \\
\mathbf{( 1 0 0 \% )}\end{array}$ \\
\hline Uro-oncological conditions & $37(2.6)$ & $28(1.9)$ & $65(4.5)$ \\
\hline Urinary system stone disease & $4(0.3)$ & $51(3.5)$ & $55(3.8)$ \\
\hline Neurourology-incontinence & $10(0.7)$ & $4(0.3)$ & $14(1)$ \\
\hline BPH & $9(0.6)$ & $4(0.3)$ & $13(0.9)$ \\
\hline Andrology & $0(0)$ & $10(0.7)$ & $10(0.7)$ \\
\hline Others & $10(0.7)$ & $39(2.7)$ & $49(3.4)$ \\
\hline Total diagnosis & $70(4.9)$ & $136(9.4)$ & $206(14.3)$ \\
\hline
\end{tabular}

BPH: benign prostatic hyperplasia

Table 2. Distribution of urogenital system malignancies

\begin{tabular}{|c|c|}
\hline \multicolumn{2}{|l|}{ Testicular Cancer } \\
\hline Number of patients (n;\%) & $25(38.4)$ \\
\hline Disabled & $8(32)$ \\
\hline Other & $17(68)$ \\
\hline Age $($ mean $\pm \mathrm{SD})$ & $32.3 \pm 9.7$ \\
\hline Pathological subtypes (n;\%) & \\
\hline Pure Seminoma & $10(40)$ \\
\hline Non-seminomatous & $2(8)$ \\
\hline Mixed germ cell & $11(44)$ \\
\hline Others & $2(8)$ \\
\hline \multicolumn{2}{|l|}{ Bladder Cancer } \\
\hline Number of patients $(\mathrm{n} ; \%)$ & $15(23)$ \\
\hline Disabled & $11(73.3)$ \\
\hline Other & $4(26.7 \%)$ \\
\hline Age $($ mean $\pm \mathrm{SD})$ & $56.2 \pm 11$ \\
\hline \multicolumn{2}{|l|}{ Prostate Cancer } \\
\hline Number of patients $(\mathrm{n} ; \%)$ & $13(20)$ \\
\hline Disabled & $10(76.9)$ \\
\hline Other & $3(23.1)$ \\
\hline Age $($ mean \pm SD) & $57.9 \pm 7.5$ \\
\hline \multicolumn{2}{|l|}{ Renal Cancer } \\
\hline Number of patients $(\mathrm{n} ; \%)$ & $11(16.9)$ \\
\hline Disabled & $9(81.8)$ \\
\hline Other & $2(18.2)$ \\
\hline Age $($ mean $\pm \mathrm{SD})$ & $53.5 \pm 7.2$ \\
\hline Gender $(\mathrm{M} / \mathrm{F})$ & $8 / 3$ \\
\hline \multicolumn{2}{|l|}{ Pathological subtype $(\mathrm{n} ; \%)$} \\
\hline Clear cell carcinoma & $7(63.6)$ \\
\hline Papillary cell carcinoma & $2(18.2)$ \\
\hline Chromophobe cell carcinoma & $1(9.1)$ \\
\hline Urothelial carcinoma & $1(9.1)$ \\
\hline Penile Cancer (n;\%) & $1(1.5)$ \\
\hline Total number of patients (n) & 65 \\
\hline
\end{tabular}

Table 3. Distribution of urinary system stone diseases

\begin{tabular}{l|l}
\hline $\begin{array}{l}\text { Disabled } \\
\text { Other }\end{array}$ & $\begin{array}{l}4(7.3) \\
51(92.7)\end{array}$ \\
\hline Age (mean \pm SD) & $28.5 \pm 9.3$ \\
Gender (n;\%) & $6(10.9)$ \\
Male & $49(89.1)$ \\
Female & $17(30.9)$ \\
\hline Patient undergoing further & $7(12.7)$ \\
examination (n;\%) & $6(10.9)$ \\
Conservative follow-up & $4(7.3)$ \\
ESWL & 55 \\
Surgical intervention & Number of patients (n;\%) \\
\hline HUN: hydrureteronephrosis; ESWL: extracorporeal shockwave \\
lithotripsy
\end{tabular}

patients were in the metastatic stage of the disease. Kidney cancer was present in $11(16.9 \%)$ patients including $9(81.8 \%)$ patients in the disability determination group, and $2(18.2 \%)$ cases in the other group. The most common renal pathology was clear cell carcinoma. The mean age of these patients was $53.5 \pm 7.2$ years, and three $(27.2 \%)$ of them had metastatic disease at admission. One (1.5\%) patient had a diagnosis of penile cancer.

The second most common diagnostic group was stone diseases with $55(3.7 \%)$ patients and when the disability detection group was excluded from the assessments it ranked on top with an incidence rate of 3.9 percent. The mean age of the patients was $28.5 \pm 9.3$ years, and the majority of them were male patients $(n=49: 89.1 \%)$. In $17(30.9 \%)$ of these patients, further examination was required after the diagnosis, and as a result, ESWL was planned for $6(10.9 \%)$ and surgery for 4 $(7.3 \%)$ patients. The group characteristics of the stone patients are given in Table 3.

The neurourology-incontinence diagnosis group ranked third in frequency with $14(0.9 \%)$ cases. The mean age of these patients was $39.7 \pm 12.6$ years, and $10(71.4 \%)$ patients were receiving treatment with the diagnosis of neurogenic bladder. Almost half of these patients $(n=4: 40 \%)$ had a traumatic etiology. Thirteen $(0.89 \%)$ cases with a mean age of $58.3 \pm 7.6$ 
years had a diagnosis of BPH. There were $10(0.68 \%)$ patients in the andrology group, and all of these patients had a diagnosis of varicocele. The mean age of the patients was $27.2 \pm 7.1$ years, and none of them were in the disability detection group.

There were 49 (3.4\%) patients in the other group, and the majority of them were $(n=23: 46.9 \%)$ patients with solitary/ single-functioning kidney including 9 (39.1\%) patients with renal agenesis, and 7 (34.7\%) with renal atrophy/hypoplasia. Seven (30.4\%) patients had a solitary kidney due to previous nephrectomy. Patients who underwent nephrectomy with the diagnosis of renal cell carcinoma were included only in the group of 'malignancies'. The diagnoses determined in the patients applied with other indications are given in Table 4.

Table 4. Distribution of diagnoses in the other group

\begin{tabular}{l|l}
\hline Solitary/Single-functioning kidney & $23(46.9)$ \\
number of patients (n;\%) & $7(30.4)$ \\
Disabled & $16(60.6)$ \\
Other & \\
\hline Etiologies & $9(39.1)$ \\
Agenesis & $7(30.4)$ \\
Atrophy/Hypoplasia & $7(30.4)$ \\
Surgery* & $7(14.2)$ \\
\hline UPJ obstruction & $4(8.2)$ \\
Renal angiomyolipoma & $4(8.2)$ \\
Renal cyst & $3(6.1)$ \\
Urethral stenosis & $3(6.1)$ \\
Horseshoe kidney & $2(4.1)$ \\
Ectopic kidney & $2(4.1)$ \\
VUR & $1(2)$ \\
Testicular agenesis & $1(2)$ \\
Prostatic cyst & $1(2)$ \\
Bladder diverticulum & $1(2)$ \\
Solitary testis** & 49 \\
\hline Total number of patients (n;\%) & \\
\hline
\end{tabular}

UPJ: ureteropelvic junction VUR: vesicoureteral reflux; * nephrectomies performed with benign indications; ** orchiectomized due to orchitis

\section{Discussion}

When we grouped the diagnoses seen in the patients who applied to the health board according to the subspecialty areas of urology, the most common disease group was determined as genitourinary system cancers. A total of 65 uro-oncological pathologies were detected in 63 different cases. In order to determine the prevalence of serious cancer types at a national level in our country, cancer records are collected by the Cancer Control Department of the Ministry of Health, and evaluations are made on the data obtained by considering gender and demographic data of the patients. The data have shown that the incidence of cancer is increasing every year [5]. According to the report of Turkey Cancer Statistics, prostate cancer is the most common cancer (13\%) in men in all age groups in Turkey after lung and respiratory tract cancers. While bladder cancer takes the fourth $(8,1 \%)$, and kidney tumors the sixth place $(2,9 \%)$. Testicular cancer is not in the top ten in all age groups. In women, on the other hand, none of the urological cancers are found in the top ten [6].

In our study, testicular cancer patients constituted the majority $(39.1 \%)$ of the cancer patients who applied to the health board. Although its frequency is low among urological cancers, testicular cancer was the most common urogenital cancer detected in our study which seems to be due to our relatively young patient population. In addition, the conditions that increase the reasons for admission, such as compulsory military service examination of the patients orchiectomized due to testicular tumor seem to increase the number of cases with testicular cancer applying to the disability health board. Testicular cancers account for $1 \%$ of all adult malignancies and $5 \%$ of urological tumors [7]. The most common cancer in men in the 15-24 age group in Turkey is testicular cancer with a rate of 24.3 percent [6]. The peak incidence is seen in the third decade of life for non-seminomatous and mixed germ cell tumors, and in the fourth decade for pure seminoma [7]. As a result of the sensitivity of testicular cancer to chemotherapy, development of cisplatin-based treatment modalities, multidisciplinary approaches, close patient follow-ups, and increased salvage treatment options, long-term survival rates are between $80-90 \%$, even in metastatic disease [8].

The second most common oncological diagnosis in our patient group was bladder cancer. Bladder cancer is the seventh most frequently diagnosed cancer in the male population worldwide and the tenth most common cancer for both sexes. It is approximately four times more common in men than in women [9]. At the time of diagnosis, in one-third of the patients, the disease is limited to the mucosa (Ta, carcinoma in situ) or submucosa (T1) [10]. These patients have much better survival rates than patients with T2-T4 tumors [9]. T stages of the patients were not examined in our study, but it was found that $40 \%$ of them were cystectomized. Since it is a surgical procedure that causes organ loss and some degree of disability, this rate is expected to be high. The reason why bladder cancer was found in the second frequency in our study was the applications made for the detection of disability due to this morbid surgical procedure.

Prostate cancer is the second most common cancer in men in Turkey and in the world. It is the most common urogenital cancer [6,11]. In 2012 alone, 1.1 million people were diagnosed with prostate cancer worldwide, which corresponds to $15 \%$ of all diagnosed cancers for that year [11]. In Western societies, it is relatively more common, and its frequency is increasing with the widespread use of prostate-specific antigen (PSA) screenings [11]. In an epidemiological study conducted by Zorlu et al., in 2014 covering 12 cities, the incidence of prostate cancer in Turkey was found to be 35/100,000, with the highest rate in Istanbul with 43.7/100,000 and the lowest in Edirne with $17.7 / 100,000$ [12]. It can be thought that prostate cancer was seen less frequently in our study compared to its incidence in the literature, besides its definitive treatment was relatively less morbid with lower incidence of metastatic diseases resulting in decreased need for health board applications. The reason why a 
significant portion of the patients (38.7\%) who applied had the metastatic disease can be explained by the fact that most of the patients (76.9\%) applied for the detection of disability.

Kidney tumors are usually asymptomatic, and their incidence has increased in recent years due to incidental diagnosis with radiological examinations [13]. Renal cell carcinoma represents about $3 \%$ of all cancers, with the highest incidence in Western countries. The highest incidence rates in Europe and worldwide are detected in the Czech Republic and Lithuania [14]. It is the most common solid lesion of the kidney and represents $90 \%$ of all renal malignancies. As for renal malignancies, men have a 1.5:1 dominance compared to women, and a higher incidence is noted in the elderly population [15]. In our study, a total of 11 cases including $8(72.7 \%)$ male patients had renal tumors, and all but one had renal cell carcinoma. This rate was consistent with the literature.

Urinary system stones were the second most common urological disease group in patients applied to the health board. Although urolithiasis is more frequently seen in some regions, it is a common public health problem all over the world [16]. Its incidence ranges from $1 \%$ to $20 \%$ depending on the genetic, environmental factors, and dietary habits [17].

In epidemiological studies conducted in our country, prevalence rates of urinary system stones were found to range between $11.1 \%$ and $14.8 \%$, and they were seen 1.5 times more frequently in males than in females $[18,19]$. The lowest, and the highest prevalence rates were observed in The Black Sea (9.5\%), and Aegean Regions (12.6\%), respectively. In the Marmara Region, its prevalence was found to be 11.4 percent [19]. In our study, the prevalence of stone disease was found to be $3.8 \%$, and almost all these patients were male (89.1\%). The reason for the lower incidence of stone disease compared to the literature is that our patient population was mostly asymptomatic, and they applied to the hospital usually for other indications. This fact may explain the low rate of definitive treatment applications $(10.9 \%)$. In addition, the stone disease was most commonly seen $(3.9 \%)$ in patients not evaluated in the disability detection group.

It should be noted that one-tenth of these patients who applied for completely different reasons were directed to further treatment with the diagnosis of incidental urinary system stone disease, and surgery was planned for $7.3 \%$ of the whole group. This shows us that the health board can also work with a focus on treatment.

The third disease group comprised patients with neurological causes of incontinence, and the majority (71.4\%) of this group consisted of patients with a diagnosis of neurogenic bladder. Neurogenic bladder is a lower urinary system disorder secondary to nervous system damage or diseases. Multiple sclerosis, Parkinson's disease, spina bfida, and diabetic neuropathy, and spinal cord injury play a role in its etiopathogenesis [20]. In a study conducted with people with locomotor system disabilities in our country, one of the most common additional pathologies was found to be neurogenic bladder [21]. In our study, the most important etiologic factor was determined as trauma such as falling from a height or traffic accident. Approximately 12,000 new cases are recorded each year in the United States (US) [22]. Some degree of impairment of bladder function has been reported within one year after a traumatic incident in approximately $81 \%$ of these patients [23].

$\mathrm{BPH}$ is the most important cause of lower urinary tract symptoms (LUTS) in men. It is the most common benign neoplasia in aging men, with a frequency of $8 \%$ in the fourth and $90 \%$ in the ninth decade of life [24]. In our country, although there is no direct study to determine the prevalence of $\mathrm{BPH}$, in the study of Uluocak et al., its prevalence rates varied between $4.1 \%$ and $34.9 \%$ according to different diagnostic criteria of benign prostatic obstruction [25]. In the study of Ak1 et al., only $14.8 \%$ of the cases in all age groups had not LUTS [26]. Although BPH and LUTS do not exactly overlap, they almost always coexist, and it has been reported in previous publications that it may provide insight into the prevalence of BPH [27]. In our study, the prevalence of BPH was $0.89 \%$ in the general group, while it was $5.9 \%$ in the disability detection group consisting of older patients. These numbers fall far behind the literature data. The biggest reason for this is that $\mathrm{BPH}$ is not seen as a disability and is not a remarkable diagnosis in terms of the health board criteria, so it is not recorded and/or questioned.

Another urological diagnosis observed in our study was varicocele $(0.68 \%)$. Varicocele is the most important, and known cause of male infertility. It is seen in $15-20 \%$ of the otherwise healthy male population, and in $25 \%$ of men with defective spermatogenesis. This rate rises to $35-40 \%$ in men under investigation for infertility [28]. In our study, the diagnosis of varicocele was seen at a low rate not comparable with the literature data. Because the diagnosis of varicocele, just like $\mathrm{BPH}$, is not an important issue in the decision-making in patients applied to the health board.

Half of the patients (46.9\%) we examined under the heading of the other group consisted of patients with solitary/ single-functioning kidneys, and the percentage of patients nephrectomized due to kidney tumors was not included in this estimation. The causes of the solitary kidney are usually unilateral renal agenesis, congenital hypoplasia/dysgenesis and surgeries. The prevalence of renal agenesis is 3.3 per 10,000 live births [29]. In our patient group, renal agenesis seems to be the most important cause of solitary kidney with 39.1 percent. However, when patients nephrectomized due to kidney tumors were added to this group, surgery seemed to be the most important etiologic factor.

The most important limitation of our study is that due to the diagnostic selectivity of the health board, some diagnoses were identified less than they actually are. For example, urological pathologies such as varicocele, BPH or kidney cyst, which are frequently seen in the community, are not important in the assessments of the health board, do not constitute a disability or defect, therefore they are not questioned and recorded.

\section{Conclusion}

Urogenital system malignancies and urinary system stones have been identified as the most common pathologies in patients applied to the health board. Although our patient population does not directly reflect the condition in Turkey in general, it may be a benchmark for larger-scale studies.

In addition, the fact that some diseases, especially urolithiasis which were diagnosed incidentally in the examinations made 
for the determination of health status, with further examination and treatment shows the contribution of the health board examinations to the treatment as well as determination of the health status.

Ethics Committee Approval: The study was approved by University of Health Sciences, Dr. Sadi Konuk Training and Research Hospital Ethical Committee, Bakirkoy, Istanbul, Turkey (Approval No: 2021/187).

Informed Consent: An informed consent was obtained from all the patients for research.

Publication: The results of the study were not published in full or in part in form of abstracts.

Peer-review: Externally peer-reviewed.

Authorship Contributions: Any contribution was not made by any individual not listed as an author. Concept - D.N.O., E.G.; Design - D.N.O., E.G.; Supervision - D.N.O., E.G.; Resources - D.N.O., E.G.; Materials - D.N.O., E.G.; Data Collection and/ or Processing - D.N.O., E.G.; Analysis and/or Interpretation D.N.O., E.G.; Literature Search - D.N.O., E.G.; Writing D.N.O., E.G.; Critical Review - D.N.O., E.G.

Conflict of Interest: The authors have declared that they have no conflict of interest.

Financial Disclosure: The authors have declared that this study received no financial support.

\section{References}

[1] Binar M, Öçal FCA, Karaçaylı C, Ünlü ECE, Aşık MB, Canda B. The Distribution of Ear, Nose, Throat Diseases in Disability Board Reports and Their Place in Total Disability Rates. KBB-Forum 2019;18:44-52. http://kbb-forum.net/journal/text.php?lang=tr\&id=428.

[2] Özürlülük Ölçütü, Sınıflandırması ve Özürlülere Verilecek Sağlık Kurulu Raporları Hakkında Yönetmelik. [Regulation on Disability Criteria, Classification and Health Board Reports to be Given to the Disabled]. Aile ve Sosyal Politikalar Bakanlığı. 28173 Sayılı Resmi Gazete, 14 Ocak 2012, Ankara.

https://www.resmigazete.gov.tr/eskiler/2013/03/20130330-4.htm

[3] Çabalar M, Tatlıdede AD, Yazar T, Güveli B, Yayla V. Evaluation of the neurological disability rates in medical commission. Med J Bakirkoy 2011;7:142-6. https://doi:10.5350/BTDMJB201107404.

[4] Ceyhan D, Yaşar T, Demirok A, Çınal A, Esmer O, Batur M. Causes of Visual Impairment in the Van City Area According to the Health Committee's Reports. TJO 2012;42:131-4.

https://doi:10.4274/tjo.42.63835.

[5] Aydin S. The Incidence of Urinary Cancers in Turkey. Turk J Urol 2007;33:392-7.

https:/turkishjournalofurology.com/EN/december-2007-0028.

[6] Kara F, Keskinkılıç B. Türkiye Kanser İstatistikleri [Turkey Cancer Statistics]. Sağlık Bakanlığı, Türkiye Halk Sağlığı Kurumu 2016.

https://hsgm.saglik.gov.tr/tr/kanser-istatistikleri.
[7] Park JS, Kim J, Elghiaty A, Ham WS. Recent Global Trends in Testicular Cancer Incidence and Mortality. Medicine (Baltimore) 2018;97:e12390. https://doi:10.1097/MD.0000000000012390.

[8] Jones A, Fergus JN, Chapman J, Houghton L. Is Surveillance for Stage I Germ Cell Tumours of the Testis Appropiate Outside a Specialist Centre? BJU Int 1999;84:79-84. https://doi:10.1046/j.1464-410x.1999.00058.x.

[9] IARC, Cancer Today. Estimated Number of New Cases in 2020, Worldwide, Both Sexes, all Ages, 2021. https://gco.iarc.fr/today/online-analysis-table.

[10] Compérat E, Larré S, Roupret M, Neuzillet Y, Pignot G, Quintens H, et al. Clinicopathological Characteristics of Urothelial Bladder Cancer in Patients Less Than 40 Years Old. Virchows Arch 2015;466:589-94. https://doi:10.1007/s00428-015-1739-2.

[11] Ferlay J, Soerjomataram I, Dikshit R, Eser S, Mathers $\mathrm{C}$, Rebelo $\mathrm{M}$, et al. Cancer Incidence and Mortality Worldwide: Sources, Methods and Major Patterns in GLOBOCAN 2012. Int J Cancer 2015;136:359-86.

https://doi:10.1002/ijc.29210.

[12] Zorlu F, Zorlu R, Divrik RT, Eser S, Yorukoglu K. Prostate Cancer Incidence in Turkey: An Epidemiological Study. Asian Pac J Cancer Prev 2014;15:9125-30. https://doi:10.7314/apjcp.2014.15.21.9125.

[13] Güner E, Danacıoğlu YO, Arıkan Y, Ekşi M, Şam E, Hüseynov J, et al. Benign Lesions Detected in Patients Undergoing Nephrectomy for Renal Mass: Single Center Experiences. J Reconstr Urol 2019;9:73-8. http://doi:10.5336/urology.2019-72133.

[14] Capitanio U, Bensalah K, Bex A, Boorjian SA, Bray F, Coleman J, et al. Epidemiology of Renal Cell Carcinoma. Eur Urol 2019;75:74-84.

http://doi:10.1016/j.eururo.2018.08.036.

[15] Tahbaz R, Schmid M, Merseburger AS. Prevention of Kidney Cancer Incidence and Recurrence: Lifestyle, Medication and Nutrition. Curr Opin Urol 2018; 28: 62-79. https://doi:10.1097/MOU.0000000000000454.

[16] Güner E, Şeker KG. Contents of Urinary System Stones in North Marmara Region and Their Distribution by Gender. J Urol Surg 2020;7:33-6. https://doi:10.4274/jus.galenos.2019.3037.

[17] Türk C, Neisius A, Petrik A, Seitz C, Skolarikos A, Thomas K. EAU Guidelines on Urolithiasis 2018. https:/uroweb.org/guideline/urolithiasis/.

[18] Akinci M, Esen T, Tellaloğlu S. Urinary Stone Disease in Turkey: An Updated Epidemiological Study. Eur Urol 1991;20:200-3. https://doi:10.1159/000471700.

[19] Muslumanoglu AY, Binbay M, Yuruk E, Akman T, Tepeler A, Esen T, et al. Updated Epidemiologic Study of Urolithiasis in Turkey. I: Changing Characteristics of Urolithiasis. Urol Res 2011;39:309-14. https://doi:10.1007/s00240-010-0346-6. 
[20] Ginsberg D. The Epidemiology and Pathophysiology of Neurogenic Bladder. Am J Manag Care 2013;19:191-6. https://pubmed.ncbi.nlm.nih.gov/24495240/.

[21] Terzi R, Altın F. Examination of the Locomotor System Disabilities of the Patients Evaluated in the Health Board for the Disabled. Turk J Osteoporos 2014;20:60-4. https://dx.doi.org/10.4274/tod.40427.

[22] Jeong SJ, Cho SY, Oh SJ. Spinal Cord/Brain Injury and the Neurogenic Bladder. Urol Clin North Am 2010;37:537-46. https://doi:10.1016/j.ucl.2010.06.005.

[23] Ku JH. The Management of Neurogenic Bladder and Quality of Life in Spinal Cord Injury. BJU Int 2006;98:739-45. https://doi:10.1111/j.1464-410X.2006.06395.x.

[24] Lim KB. Epidemiology of Clinical Benign Prostatic Hyperplasia. Asian J Urol 2017;4:148-51. https://doi:10.1016/j.ajur.2017.06.004.

[25] Uluocak N, Şanlı Ö, Gül H, Özkan L, Özden YI, Kıyak M, et al. A Population Based Epidemiological Study on Benign Prostatic Obstruction in a Suburban District of
Istanbul. Turk J Urol 2009;35:170-9. https:/turkishjournalofurology.com/EN.

[26] Aki FT, Aygun C, Bilir N, Erkan I, Ozen H. Prevalence of Lower Urinary Tract Symptoms in a Community-based Survey of Men in Turkey. Int J Urol 2003;10:364-70. https://doi:10.1046/j.1442-2042.2003.00638.x.

[27] Dönmez İ, Mungan A. Prevalance of BPH: National Realities. Bull Urooncol 2011;4:11-4. http://cms.galenos.com.tr/Uploads/Article_8268/11-14.pdf.

[28] Masson P, Brannigan RE. The Varicocele. Urol Clin North Am 2014;41:129-44. https://doi:10.1016/j.ucl.2013.08.001.

[29] Delmas HL, Kohler M, Doray B, Lémery D, Francannet C, Quistrebert J, et al. Congenital Unilateral Renal Agenesis: Prevalence, Prenatal Diagnosis, Associated Anomalies. Data from Two Birth-defect Registries. Birth Defects Res 2017;109:1204-11. https://doi:10.1002/bdr2.1065. 